\title{
Status Gizi Wanita dengan Sindrom Ovarium Polikistik (SOPK)
}

\author{
Erna Yovi Kurniawati ${ }^{1 *}$, Suharyo Hadisaputro ${ }^{2 *}$, Agus Suwandono ${ }^{3 *}$ \\ 1 Politeknik Kesehatan Ummi Khasanah, Yogyakarta, Indonesia \\ 2 Politeknik Kesehatan Kemenkes Semarang, Jawa Tengah, Indonesia \\ 3 Universitas Diponegoro, Semarang, Jawa Tengah, Indonesia \\ *yovi.raharjanto@gmail.com, suharyo.hadisaputro@gmail.com, agus.suwandono@gmail.com
}

\section{ARTICLE INFO}

\section{Article history:}

Received Jannuary 23, 2022

Accepted January 25, 2022

Published January 25, 2022

\section{Kata Kunci:}

Status Gizi

Pola Diet

Aktivitas Fisik

Sindrom Ovarium Polikistik

Key words:

Nutritional Status

Dietary Habit

Physical Activity

Polycistic Ovarian Syndrome

DOI:

https://10.48092/jik.v8i1.164

\section{ABSTRAK}

Latar belakang: Lebih dari dua pertiga (69\%) wanita usia 18-40 tahun mengalami kegemukan atau obesitas, wanita SOPK yang kelebihan berat badan atau obesitas mewakili kelompok besar berisiko mengalami kardiometabolik dan gangguan psikologis. Metode: Penelitian Deskriptif Kuantitatif mengukur status gizi, pola diet, dan aktivitas fisik wanita dengan sindrom ovarium polikistik. Metode sampling menggunakan purposive sampling dengan jumlah responden 30 orang. Hasil: Status gizi reponden $56 \%$ obesitas tingkat II, seluruh responden mengalami overweight. Pengalaman diet responden $23 \%$ yang pernah melakukan program diet, sedangkan aktivitas olahraga $73 \%$ tidak melakukan olahraga. Kesimpulan: Obesitas berhubungan erat dengan resistensi insulin, sehingga pola diet dan aktivitas fisik sangat dibutuhkan guna membantu pengobatan sindrom ovarium polikistik.

\section{ABSTRACT}

Nutritional Status of Woman with Polycistic Ovary Syndrome (PCOS)

Background: More than two-thirds (69\%) of women aged 18-40 years are overweight or obese, SOPK women who are overweight or obese represent a large group at risk for cardiometabolic and psychological disorders. Methods: Quantitative Descriptive Research measuring nutritional status, dietary patterns, and physical activity of women with polycystic ovary syndrome. The sampling method used purposive sampling with the number of respondents 30 people. Results and Discussion: The nutritional status of respondents was $56 \%$ obese at level II, all respondents were overweight. The dietary experience of $23 \%$ of respondents who had done a diet program, while $73 \%$ of sports activities did not do exercise. Conclusion: Obesity is closely related to insulin resistance, so diet and physical activity patterns are needed to help treat polycystic ovary syndrome.

ThisopenaccessarticleisundertheCC-BY-SAlicense. 


\section{PENDAHULUAN}

Resistensi insulin paling sering menjadi dasar SOPK, dengan gangguan toleransi glukosa dan diabetes tipe 2, faktor risiko utama penyakit jantung, obesitas, hipertensi, dislipidemia, peradangan, disfungsi endotel, dan aterosklerosis subklinis. Meningkatkan faktor risiko terjadinya kardiometabolik dan penyakit lain yang terkait dengan SOPK. Risiko jangka panjang yang mungkin dialami wanita dengan sindrom ovarium polikistik adalah risiko terkena kanker endometrium dibandingkan dengan wanita tanpa infertilitas, keguguran, dan termasuk risiko mengalami kanker payudara dua kali lipat sampai tiga kali lebih tinggi ${ }^{1}$.

Lebih dari $50 \%$ pasien SOPK dikaitkan dengan sindrom metabolik termasuk obesitas, resistensi insulin, dan dislipidemia. Insiden kejadian SOPK pada remaja \pm sebesar $11-26 \%$, dan sekitar $50 \%$ diantaranya overweight. ${ }^{2}$ Studi baru menujukkan bahwa SOPK mempengaruhi 2,2-20\% dari wanita dengan usia reproduksi. ${ }^{3}$ Suatu studi menunjukkan bahwa prevalensi SOPK lebih tinggi pada wanita dengan berat badan berlebih, obesitas, dan hingga $30 \%$ wanita yang memiliki IMT $>30 \mathrm{~kg} / \mathrm{m} 2$ memenuhi kriteria diagnostik SOPK. ${ }^{1}$ Berat badan berlebih berpengaruh terhadap subfertilitas pada seorang wanita dan dapat mempengaruhi organ reproduksi yang menyebabkan menstruasi tidak teratur, subfertilitas, Sindrom Ovarium Polikistik (SOPK), kanker rahim, endometrium, payudara, dan serviks. ${ }^{4}$

Pasien SOPK memiliki kecenderungan untuk mengkonsumsi makanan dengan indeks glikemik yang tinggi. Asupan energi harian total seorang wanita dihitung sebagai persentase dari asupan Angka Kecukupan Gizi (AKG) berdasarkan kebutuhan nutrisi wanita usia reproduksi. Wanita dengan SOPK memiliki asupan kalori yang lebih tinggi daripada wanita yang tidak menderita SOPK. Selain itu, konsumsi tinggi lemak dan peningkatan asupan protein, dilihat terlibat dalam obesitas abdominal dan gangguan fungsi pankreas dalam sekresi insulin, sehingga dapat mengakibatkan Sindroma Ovarium Polikistik (SOPK). ${ }^{5}$

\section{METODE}

Penelitian ini merupakan penelitian deskriptif

kuantitatif yang mengukur Status gizi wanta dengan indikator Indeks Masa Tubuh (IMT), pola diet dan aktivitas fisik. Populasi terjangkau dalam penelitian ini adalah wanita dengan diagnosis sindrom ovarium polikistik usia 19-40 tahun di Yogyakarta. Populasi terjangkau berdasarkan data rekrutmen yang terkumpul dalam penelitian ini berjumlah 53 orang. Sampel penelitian adalah populasi terjangkau yang memenuhi syarat untuk berpartisipasi, dengan memenuhi kriteria inklusi dan ekslusi. Kriteria Inklusi: 1) Usia 19-40 tahun, 2) Terdiagnosis mengalami sindrom ovarium polikistik berdasarkan kriteria Rotterdam oleh dokter spesialis obstetri ginekologi, 3) Mampu membaca dan menulis bahasa Indonesia, 4) Peserta mengisi inform consent. Kriteria Eksklusi: 1) Hamil (dibuktikan dengan uji kehamilan menggunakan PP Test saat seleksi), 2)

Faktor genetik menderita sindrom ovarium polikistik. Metode sampel menggunakan purposive sampling, dari 53 orang populasi diseleksi berdasarkan kriteria inklusi dan eksklusi didapatkan jumlah sampel 30 orang.

Metode pengumpulan data menggunakan kuesioner dan lembar observasi.

\section{HASIL DAN PEMBAHASAN}

\section{Karakteristik Responden}

Tabel 1 Gambaran Karakteristik Responden

\begin{tabular}{llc}
\hline \multicolumn{1}{c}{ Kategori } & $\mathrm{n}$ & $\%$ \\
\hline Usia (Mean \pm SD) & \multicolumn{2}{c}{$(30.4 \pm 2.376)$} \\
Min-max & \multicolumn{2}{c}{$27-36$} \\
$27-30$ th & 19 & 63.3 \\
$31-36$ th & 11 & 36.6 \\
Total & 30 & 100.0 \\
\hline Lama Menikah (Mean \pm SD) & \multicolumn{2}{c}{$(4.56 \pm 1.784)$} \\
Min-max & \multicolumn{2}{c}{$2-8$} \\
2-4 th & 15 & 50.0 \\
5-8 th & 15 & 50.0
\end{tabular}


(JIK) JURNAL ILMU KEBIDANAN 8 (1) Desember 2021

$P$ ISSN 2407-6872 E ISSN 2579-4027

Thisopenaccessarticleisunderthe $C C-B Y$-SAlicense.

\begin{tabular}{|c|c|c|}
\hline Kategori & $\mathrm{n}$ & $\%$ \\
\hline Total & 30 & 100.0 \\
\hline Lama Pengobatan & \multirow{2}{*}{\multicolumn{2}{|c|}{$(24.93 \pm 12.829)$}} \\
\hline$($ Mean \pm SD $)$ & & \\
\hline Min-max & \multicolumn{2}{|c|}{$6-48$} \\
\hline $6-24$ bln & 18 & 60.0 \\
\hline $25-48$ bln & 12 & 40.0 \\
\hline Total & 30 & 100.0 \\
\hline \multicolumn{3}{|l|}{ Pendidikan } \\
\hline S1 & 25 & 83.4 \\
\hline S2 & 5 & 16.6 \\
\hline Total & 30 & 100.0 \\
\hline \multicolumn{3}{|l|}{ Pekerjaan } \\
\hline Ibu rumah tangga & 3 & 10 \\
\hline Wiraswasta & 2 & 6.6 \\
\hline Swasta & 18 & 60.0 \\
\hline PNS & 7 & 23.4 \\
\hline Total & 30 & 100.0 \\
\hline
\end{tabular}

Berdasarkan Tabel 1, responden berada pada usia reproduktif, dengan usia rata-rata 30 tahun, semuanya mengalami infertilitas pada rentang 2-8 tahun, dan ratarata lama menikah 4,5 tahun. Durasi pengobatan untuk infertilitas berkisar antara 6 bulan sampai 4 tahun, dengan rata-rata pengobatan 25 bulan. Seluruh responden berlatar pendidikan perguruan tinggi pada tingkat sarjana dan pascasarjana. Sebagian besar pekerjaan responden sebagai pegawai swasta.

Usia merupakan faktor pembatas dalam penelitian ini dengan batas usia 19-40 tahun diperlukan sehubungan dengan sindrom ovarium polikistik umumnya didiagnosis pada usia reproduksi atau usia subur wanita. Tingkat pendidikan formal dapat meningkatkan konsep diri dalam menghadapi masalah dan stresor. Jenis pekerjaan sering dikaitkan dengan penentuan stresor seseorang. Pekerjaan mengacu pada aktivitas dan interaksi yang mempengaruhi orang dengan memberikan informasi tentang kesehatan. Lama menikah terkait dengan penetapan atau diagnosis infertilitas. Lama pernikahan juga dikaitkan dengan stresor pada wanita dengan sindrom ovarium polikistik. Durasi pengobatan untuk sindrom ovarium polikistik mempengaruhi

Status gizi reponden $56 \%$ obesitas tingkat II, seluruh responden mengalami overweight. Status gizi berdasarkan hasil penelitian ini memberikan gambaran tingginya resiko sindrom metabolik yang menyertai. Hasil pemeriksaan status gizi responden, seluruh responden dalam kategori overweight (klasifikasi berdasarkan World Health Organization), terdapat 3 responden (10\%) dalam kategori beresiko, 9 responden (30\%) dalam kategori obesitas I, dan 18 responden $(60 \%)$ dalam kategori obesitas II. Ketidakseimbangan antara asupan makanan tinggi energi dengan pengeluaran energi untuk aktivitas dalam jangka waktu lama memungkinkan terjadinya obesitas, resistensi insulin dan DM tipe $2^{7}$.

Potensi kerja insulin akan menurun dengan bertambahnya timbunan lemak. Korelasi negatif antara potensi kerja insulin dengan timbunan lemak bukanlah merupakan garis linear, tetapi ada daerah kritis yaitu dari berat badan lebih (overweight) ke obesitas ringan potensi kerja insulin akan menurun tajam, yang selanjutnya semakin berat obesitas akan diikuti dengan penurunan 
yang lebih rendah dari potensi kerja insulin. Asupan makanan tinggi energi yang berlebihan akan memacu resistensi insulin melalui peningkatan kadar gula darah dan asam lemak bebas di dalam darah. Asupan makanan tinggi energi juga menyebabkan peningkatan lemak tubuh sehingga timbul obesitas. Obesitas sentral telah diketahui berhubungan erat dengan resistensi insulin ${ }^{8,9}$, 10.

Pengobatan standar SOPK tanpa adanya pendamping terapi fisik dengan pengelolaan diet serta olahraga tidak efektif menurunkan kadar resistensi insulin. Pada penelitian Kurniawati, resistensi insulin menurun setelah diberikan pengobatan standar dan program holistik selama 2 minggu. Program holistik merupakan kombinasi terapi mindfulness, pengaturan diit dan aktivitas fisik. Hasil statistik menunjukkan bahwa program holistik berpengaruh menurunkan kadar resistensi insulin, akan tetapi belum efektif secara klinis menjadikan kondisi sensitive insulin ${ }^{11}$.

\section{KESIMPULAN DAN REKOMENDASI}

Pola hidup dengan pengaturan pola makan dan aktivitas fisik berkaitan dengan status gizi wanita dengan sindrom ovarium polikistik. Diketahui status gizi yang berlebih akan memicu terjadinya peningkatan kortisol hormon dan memicu resistensi insulin, sehingga diperlukan terapi pendamping non farmakologis berupa kombinasi pengaturan diit dan aktivitas fisik pada pengobatan wanita dengan sindrom ovarium polikistik.

Diperlukan penelitian terapan lebih lanjut tentang kombinasi terapi pendamping yang dapat menurunkan resistensi insulin pada wanita dengan sindrom ovarium polikistik.

\section{REFERENSI}

1. Boyle JA, Cunningham J, O'Dea K, Dunbar T, Norman RJ. Prevalence of polycystic ovary syndrome in a sample of Indigenous women in
Darwin, Australia. Med J Aust. 2012;196(1):62-6.

2. Ojaniemi M, Pugeat M. An adolescent with polycystic ovary syndrome. Eur J Endocrinol. 2006;155(suppl_1):S149-52.

3. Singh A, Vijaya K, Laxmi KS. Prevalence of polycystic ovarian syndrome among adolescent girls: a prospective study. Int $\mathbf{J}$ Reprod Contracept Obs Gynecol. 2018;7(11):4375-8.

4. Chavarro JE, Rich-Edwards JW, Rosner BA, Willett WC. Use of multivitamins, intake of B vitamins, and risk of ovulatory infertility. Fertil Steril. 2008;89(3):668-76.

5. Douglas CC, Norris LE, Oster RA, DarnellBE, Azziz R, Gower BA. Difference in dietary intake between women with polycystic ovary syndrome and healthy controls. Fertil Steril. 2006;86(2):411-7.

6. Bazarganipour F, Ziaei S, Montazeri A, Foroozanfard F, Kazemnejad A, Faghihzadeh S. Psychological investigation in patients with polycystic ovary syndrome. Int $J$ of Health and quality of life outcomes [Internet]. 2013 [cited 2018 Mar 03]; 11(1):[141 p.]. Available from: https://doi.org/10.1186/1477-7525-11-141.

7. Diamanti-Kandarakis E, Christakou CD. Insulin resistance in PCOS. Diagnosis and Management of Polycystic Ovary Syndrome, https://doi.org/10.1007/978-0-387-09718-3_4.

Boston, MA: Springer; 2009. p. 35-61.

8. Kim JJ, Choi YM. Dyslipidemia in women with polycystic ovary syndrome. Int J Obstetrics \& gynecology science [Internet]. 2013 [cited 2018 Jun 12]; 56(3):[137-42 pp.]. Available from: http://dx.doi.org/10.5468/ogs.2013.56.3.137.

9. Legro RS, editor Obesity and PCOS: implications for diagnosis and treatment. Seminars in reproductive medicine; 2012: NIH Public Access.

10. Irene, A., Alkaf, S., Zulissetiana, E. F., Usman, F., \& Larasaty, V. (2020). Hubungan Pola Makan dengan Risiko Terjadinya Sindrom Ovarium Polikistik pada Remaja. Sriwijaya Journal of Medicine, 3(1), 65-72.

11. Kurniawati, E. Y., Hadisaputro, S., \& Suwandono, A. (2019). The Effect of Holistic Programs on Cortisol Serum Levels in Polycistic Ovarium Syndrome. Indonesian Journal of Medicine, 4(4), 376-382. 